University of Nebraska - Lincoln

DigitalCommons@University of Nebraska - Lincoln

Agronomy \& Horticulture -- Faculty Publications

Agronomy and Horticulture Department

5-20-2004

\title{
Stability of the allergenic soybean Kunitz trypsin inhibitor
}

\author{
Robin Roychaudhuri \\ University of Nebraska-Lincoln \\ Gautam Sarath \\ University of Nebraska-Lincoln, Gautam.sarath@ars.usda.gov \\ Michael G. Zeece \\ University of Nebraska-Lincoln, mzeece1@unl.edu \\ John P. Markwell \\ University of Nebraska-Lincoln, jmarkwell2@unl.edu
}

Follow this and additional works at: https://digitalcommons.unl.edu/agronomyfacpub

Part of the Plant Sciences Commons

Roychaudhuri, Robin; Sarath, Gautam; Zeece, Michael G.; and Markwell, John P., "Stability of the allergenic soybean Kunitz trypsin inhibitor" (2004). Agronomy \& Horticulture -- Faculty Publications. 19. https://digitalcommons.unl.edu/agronomyfacpub/19

This Article is brought to you for free and open access by the Agronomy and Horticulture Department at DigitalCommons@University of Nebraska - Lincoln. It has been accepted for inclusion in Agronomy \& Horticulture -Faculty Publications by an authorized administrator of DigitalCommons@University of Nebraska - Lincoln. 


\title{
Stability of the allergenic soybean Kunitz trypsin inhibitor
}

\author{
Robin Roychaudhuri ${ }^{\mathrm{a}}$, Gautam Sarath ${ }^{\mathrm{b}}$, Michael Zeece ${ }^{\mathrm{c}}$, John Markwell ${ }^{\mathrm{a}, *}$ \\ ${ }^{a}$ Department of Biochemistry, University of Nebraska, Lincoln, NE 68588-0664, USA \\ ${ }^{\mathrm{b}}$ USDA-ARS, Department of Agronomy, University of Nebraska, Lincoln, NE 68588-0915, USA \\ ${ }^{\mathrm{c}}$ Department of Food Science and Technology, University of Nebraska, Lincoln, NE 68588-0664, USA
}

Received 3 November 2003; received in revised form 23 February 2004; accepted 27 February 2004

Available online 22 March 2004

\begin{abstract}
The soybean Kunitz trypsin inhibitor (SKTI) is a $21.5 \mathrm{kDa}$ allergenic protein that belongs to the family of all antiparallel $\beta$-sheet proteins that are highly resistant to thermal and chemical denaturation. Spectroscopic and biochemical techniques such as circular dichroism (CD), ANS fluorescence and proteolysis were used to study its molecular structure under denaturing conditions such as acid and heat to which these allergens are commonly exposed during food processing. Reduction of native SKTI leads to its complete and rapid proteolysis by pepsin in simulated gastric fluid (SGF). Limited proteolysis with chymotrypsin during renaturation after heating showed that the native structure reforms at around $60{ }^{\circ} \mathrm{C}$ reversing the denaturation. $\mathrm{CD}$ spectra revealed that under acid denaturing conditions, SKTI shows major changes in conformation, indicating the possibility of a molten structure. The existence of this intermediate was established by ANS fluorescence studies at different concentrations of $\mathrm{HCl}$. The remarkable stability of SKTI to both thermal and acid denaturation may be important for its role as a food allergen.
\end{abstract}

(C) 2004 Elsevier B.V. All rights reserved.

Keywords: Acid denaturation; CD spectra; Food allergen; Simulated gastric fluid; Thermal renaturation

\section{Introduction}

Soybean Kunitz trypsin inhibitor (SKTI) is a small, monomeric and non-glycosylated protein containing 181 residues. This $21.5 \mathrm{kDa}$ non-glycosylated protein was first isolated and crystallized from soybean seeds by Kunitz [1]. It has been characterized as a food allergen in humans consuming soy proteins $[2,3]$. In addition to its presence in foods prepared with whole soybeans, SKTI is found as a contaminant in lecithin [4], a phospholipid product widely used in foods and pharmaceuticals as an emulsifier. Based on the crystal structure reported by Sweet et al. [5] and later refined by Song and Suh [6], the overall structure of SKTI is spherical with a diameter of 3-5 nm. It comprises 12 crisscrossing antiparallel $\beta$-strands, largely stabilized by hydrophobic side chains. The two disulfides bridges between Cys 39-Cys 86 and between Cys 138-Cys 145 are

\footnotetext{
Abbreviations: ANS, 8-anilino-1-napthalene sulfonate; SKTI, soybean Kunitz trypsin inhibitor; SGF, simulated gastric fluid

* Corresponding author. Tel.: +1-402-472-2924; fax: +1-402-4727842.

E-mail address: markwell@unl.edu (J. Markwell).
}

solvent-exposed and critical to its inhibitory function with the trypsin enzyme [7-9] and its resistance to thermal and chemical denaturation [10-12]. Based on circular dichroism (CD) spectra, SKTI has been classified in the $\beta$-II or the 'disordered' class of all antiparallel $\beta$-sheet proteins that have characteristic CD spectra [13].

An interesting feature of food allergens is that they are frequently resistant to denaturation and proteolysis by pepsin in the acidic conditions of the gastric environment [14]. An allergen's stability in the highly denaturing conditions of the stomach has important consequences in the maintenance of its antigenic epitopes and its allergenic potential $[15,16]$. However, few studies have been published on the structural characterization of these allergens under acidic conditions.

The exact behavior of a protein under acidic conditions results from a complex interaction among a variety of stabilizing and destabilizing forces [17]. Acid denaturation is largely driven by intramolecular charge repulsion. The extent of unfolding in acidic conditions can be less than for chemical denaturation due to the powerful folding interactions promoted by hydrophobic forces, disulfide bonds and metal ion-protein interactions [18]. Acidification can also result in the production of a molten globule structure [17], 
which is able to refold when the $\mathrm{pH}$ of the milieu is increased. $\alpha$-Helical proteins have been studied extensively in terms of acid denaturation but relatively few reports exist on the acid denaturation of proteins containing only $\beta$-sheet structures [19].

In a previous report [12], we used heating and cooling to document the reversible thermal denaturation of SKTI. In this paper, we document the stability of SKTI to acidic conditions similar to that of the stomach and reveal that the protein appears to undergo a transition from the native to an acid denatured (A state) or molten state.

\section{Materials and methods}

\subsection{Sample preparation}

SKTI (Type-1S) was obtained from Worthington Biochemical Corporation (Lot No. 51J4950). It migrated as a single band when fractionated by SDS-PAGE and its purity was assessed as $>95 \%$. SKTI was dissolved in $10 \mathrm{mM}$ sodium phosphate buffer, $\mathrm{pH} 7.2$, for these studies. Protein concentration was determined by the dye binding method of Bradford [20].

\subsection{Simulated gastric fluid (SGF) digestion}

SGF was prepared using $0.2 \% \mathrm{NaCl}, 0.32 \%$ pepsin and $0.7 \% \mathrm{HCl}$ with a final $\mathrm{pH}$ of approximately 1.2 . All SGF digestions were carried out with a substrate protein concentration of $2.5 \mathrm{mg} \mathrm{ml}^{-1}$ in a shaking water bath at $37{ }^{\circ} \mathrm{C}$ [14]. When indicated, native SKTI was incubated with 30 $\mathrm{mM}$ reducing agent for $12 \mathrm{~h}$ at $37^{\circ} \mathrm{C}$. Treated and untreated protein samples were incubated in separate assays in SGF and the extent of proteolysis followed with time. At each time point, a $20 \mu \mathrm{l}$ aliquot of the sample was removed and the reaction quenched by adding $2 \mu 1 \mathrm{~N} \mathrm{NaOH}$ and 16 $\mu 15 \times$ SDS sample denaturing buffer. The contents of the reaction were subsequently heated at $95{ }^{\circ} \mathrm{C}$ for $5 \mathrm{~min}$ and loaded on an SDS-PAGE gel for fractionation and visualized by staining with Coomassie Brilliant Blue R-250 or by Silver staining [21].

\section{3. $\mathrm{HCL} /$ water mixture}

This mixture was prepared by diluting a concentrated $\mathrm{HCl}$ stock solution $(36 \% \mathrm{w} / \mathrm{v})$ to a final concentration of $10 \%(\mathrm{w} /$ v). Further dilutions were made from this concentration or by serial dilutions. The solutions at each concentration were filtered using a $0.22 \mu \mathrm{m}$ pore nylon membrane prior to use.

\section{4. $S G F$ proteolysis during renaturation}

SKTI $\left(1 \mathrm{mg} \mathrm{ml}^{-1}\right)$ in $1 \mathrm{mM}$ sodium phosphate buffer $\mathrm{pH}$ 7.2 was heated at $90{ }^{\circ} \mathrm{C}$ for $5 \mathrm{~min}$ and then separately subjected to different renaturation protocols. Following these treatments, the SKTI was incubated in SGF $(0.4 \mathrm{mg}$ $\mathrm{ml}^{-1}$ ) at $37^{\circ} \mathrm{C}$ for $10 \mathrm{~min}$. The SGF reaction at the end of the assay was quenched by adding $1 \mu \mathrm{l} 1 \mathrm{M} \mathrm{NaOH}$ and 6 $\mu 15 \times$ SDS sample buffer $\mathrm{pH} 6.5$ [22] in a final volume of $30 \mu \mathrm{l}$ and by heating the contents at $95{ }^{\circ} \mathrm{C}$ for $5 \mathrm{~min}$. The samples were fractionated on a $10-20 \%$ acrylamide gradient SDS gel [21]. Gels were stained with Coomassie Brilliant Blue R-250 and the intensity of SKTI band on the gel was quantified from a digital image using Quantity One Software (BioRad).

\subsection{Limited proteolysis with chymotrypsin}

Limited proteolysis of SKTI with chymotrypsin II (Worthington) was carried out to determine the folding dynamics and formation of the native structure following thermal renaturation. Chymotrypsin was dissolved in $100 \mathrm{mM}$ Tris $-\mathrm{Cl} \mathrm{pH} 8.7$ and its concentration determined by Bradford protein assay method [20]. Proteolytic incubations were carried out with SKTI using a chymotrypsin/SKTI ratio of $1: 15(\mathrm{w} / \mathrm{w})$ at $37{ }^{\circ} \mathrm{C}$ in the above buffer. A sample of the SKTI solution was heated at $90{ }^{\circ} \mathrm{C}$ for $5 \mathrm{~min}$ and then renatured by cooling from 90 to $20{ }^{\circ} \mathrm{C}$ at a rate of $1{ }^{\circ} \mathrm{C}$ $\mathrm{min}^{-1}$. At regular intervals of temperature, an aliquot of SKTI was removed and treated with chymotrypsin at $37{ }^{\circ} \mathrm{C}$ for $5 \mathrm{~min}$. The proteolysis reaction was quenched by adding SDS-containing denaturing buffer and immediately heated at $95{ }^{\circ} \mathrm{C}$ for $5 \mathrm{~min}$ to denature the chymotrypsin. The entire contents of the proteolysis reaction $(8 \mu \mathrm{g}$ SKTI) were fractionated on $12.5 \%$ SDS-PAGE [22].

\subsection{CD spectroscopy}

CD spectral measurements were performed on an OLIS (On-Line Instrument Systems, Inc., Georgia). Rapid Scan Mode (RSM) CD spectrophotometer equipped with a temperature-jacketed cuvette holder. The entire instrument, including the sample chamber, was constantly flushed with nitrogen gas during the operation. All measurements were done at $37^{\circ} \mathrm{C}$. For far-UV CD spectra, $(195-245 \mathrm{~nm})$, the protein concentration was $30-40 \mu \mathrm{g} \mathrm{ml}^{-1}$. All solutions were filtered with a $0.22 \mu \mathrm{m}$ pore nylon filter prior to recording the spectra. The cuvette pathlength was $1 \mathrm{~mm}$. At each concentration of acid, the protein solution was incubated for a minimum of $5 \mathrm{~min}$ to enable sufficient equilibration at $37^{\circ} \mathrm{C}$.

\subsection{ANS fluorescence experiments}

ANS (8-anilino-1-naphthalene sulfonate) dye (Sigma) was dissolved in $100 \mathrm{mM}$ Tris- $\mathrm{Cl}, \mathrm{pH} 8.7$, to a concentration of $50 \mathrm{mM}$. The reaction was carried out in a black 96well fluorescence plate in a final volume of $300 \mu$ l. SKTI was incubated with different concentrations of acid or in SGF for $15 \mathrm{~min}$ in a $37{ }^{\circ} \mathrm{C}$ incubator with slow shaking. ANS was then added to each of the wells and mixed 
thoroughly. The final solution contained $1 \mu \mathrm{M}$ SKTI and 25 $\mu \mathrm{M}$ ANS. The fluorescence was read immediately using an excitation wavelength of $390 \mathrm{~nm}$ and emission at $460 \mathrm{~nm}$. ANS fluorescence was also done with SKTI incubated in SGF (without pepsin) under similar conditions.

\section{Results}

\subsection{SGF digestion}

SKTI was subjected to proteolysis in SGF for up to 30 min and aliquots sampled for analysis at $5 \mathrm{~s}, 2,20$ and 30 min. Native SKTI was found to be completely resistant to proteolysis for all times tested (Fig. 1A) and for as long as $60 \mathrm{~min}$. Following reduction of the native SKTI with 30 $\mathrm{mM}$ 2-mercaptoethanol, the protein appeared to be as stable as the native form (Fig. 1B). However, reduction of SKTI with $30 \mathrm{mM}$ DTT (Fig. 1C) clearly produced a form of the protein that was very sensitive to pepsin digestion in the SGF, with times as short as $5 \mathrm{~s}$ resulting in loss of the dithiothreitol-treated SKTI as compared to untreated controls.

We have previously demonstrated [12] that temperature causes a structural transition in the SKTI tertiary structure at approximately $60{ }^{\circ} \mathrm{C}$ as judged by changes in UV absorption spectra. Additionally, heating to $90{ }^{\circ} \mathrm{C}$ followed by cooling resulted in the preservation of some degree of ability to inhibit trypsin activity. Heating SKTI to $90{ }^{\circ} \mathrm{C}$ also results in some susceptibility to pepsin digestion (Fig. 2) in SGF. The extent to which the SKTI was digested depended on the manner in which it was cooled prior to mixing with the SGF. Controlled cooling at a rate of $1{ }^{\circ} \mathrm{C}$ $\min ^{-1}$ resulted a loss of only about $8 \%$ of the protein. However, rapid cooling on ice or incubation at $60{ }^{\circ} \mathrm{C}$, the mid-point for the temperature-induced changes, for $2 \mathrm{~h}$ prior to addition to SGF resulted in approximately $40 \%$ of the allergen being susceptible to hydrolysis by the pepsin as indicated by decreased protein staining intensity.

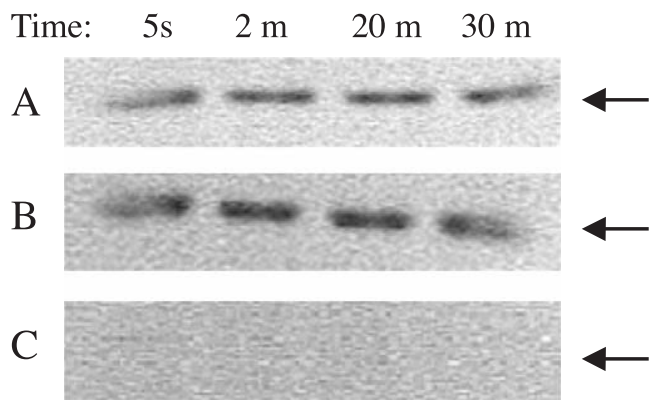

Fig. 1. SGF proteolysis of native and reduced SKTI for $5 \mathrm{~s}, 2,20$ and 30 min as analyzed by SDS-PAGE. Panel A shows native SKTI that is unreduced and treated with SGF for the indicated times. Panel B is SKTI that was reduced with $30 \mathrm{mM}$ 2-mercaptoethanol and subjected to SGF. Panel C is SKTI that was reduced with $30 \mathrm{mM}$ dithiothreitol and subjected to SGF. Arrows indicate SKTI.

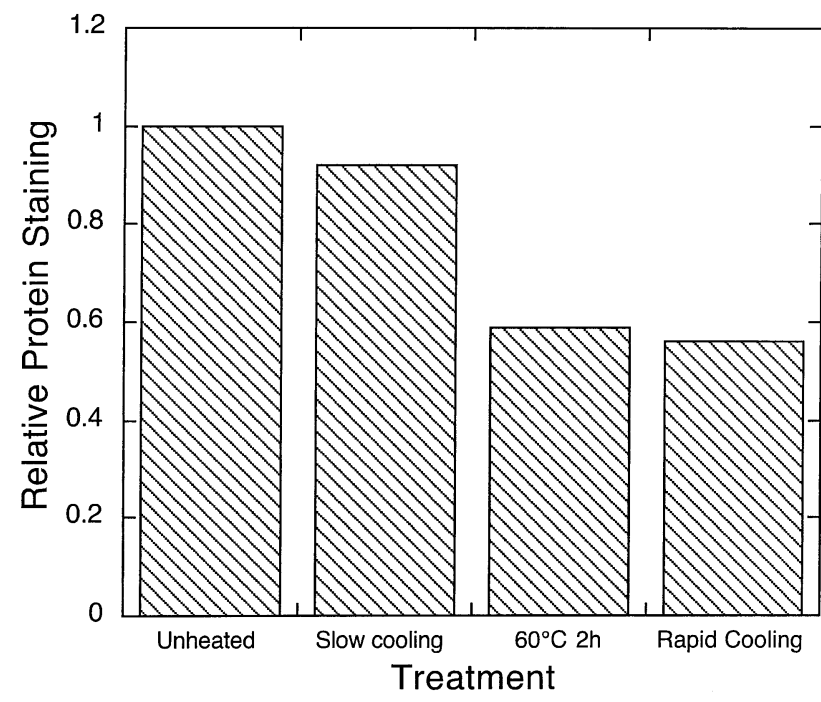

Fig. 2. SGF proteolysis of SKTI during different rates of thermal renaturation. Data is plotted as protein staining intensity versus treatments. Untreated is native inhibitor that is subjected to the thermal renaturation process without proteolysis. Slow cooling refers to renaturation at a rate of $1{ }^{\circ} \mathrm{C} \mathrm{min}{ }^{-1} .60{ }^{\circ} \mathrm{C}$ for $2 \mathrm{~h}$ refers to incubation at $60{ }^{\circ} \mathrm{C}$ for $2 \mathrm{~h}$ after quenching at $0{ }^{\circ} \mathrm{C}$. Rapid cooling is immediate quenching of SKTI from 90 to $0{ }^{\circ} \mathrm{C}$. A decrease in protein staining indicates proteolysis in SGF of the conformations of SKTI generated during these treatments.

\subsection{Thermal renaturation of SKTI}

To further study the refolding of SKTI following treatment at $90{ }^{\circ} \mathrm{C}$, we employed susceptibility to proteolysis by chymotrypsin and analysis of protein staining following SDS-PAGE fractionation. This permitted use of a more neutral $\mathrm{pH}$ to avoid complications in interpreting the effects of cooling and the low pH in SGF. The data in Fig. 3 shows that the majority of the SKTI in a sample at $90{ }^{\circ} \mathrm{C}$ was

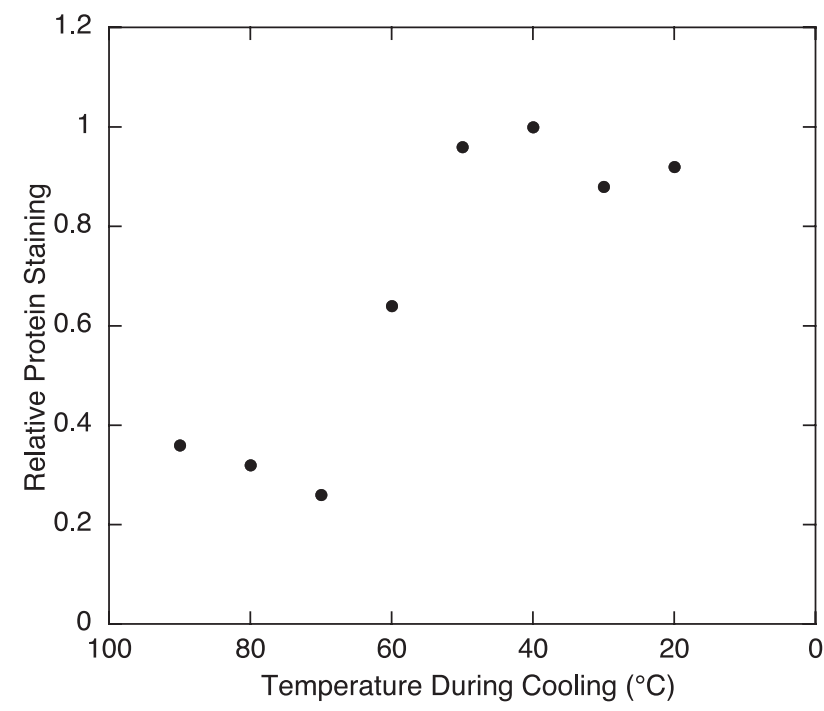

Fig. 3. Thermal renaturation of SKTI as monitored by limited proteolysis with chymotrypsin at $37{ }^{\circ} \mathrm{C}$. The plot shows protein staining relative to the unheated SKTI versus temperature during a cooling at a rate of $1{ }^{\circ} \mathrm{C}$ $\mathrm{min}^{-1}$. Higher protein intensity indicates resistance to proteolysis. 
susceptible to digestion by chymotrypsin at $37{ }^{\circ} \mathrm{C}$. However, during thermal renaturation at the rate of $1{ }^{\circ} \mathrm{C} \min ^{-1}$, resistance to chymotrypsin was regained as the sample was cooled below $70{ }^{\circ} \mathrm{C}$. This apparent renaturation resulting in resistance to chymotrypsin digestion was centered at about $60{ }^{\circ} \mathrm{C}$, coincident with the midpoint for structural changes during heating [12].

\subsection{CD spectroscopy}

Far-UV CD spectra are indicative of the extent of secondary structural changes induced in proteins by environmental changes. SKTI has a CD spectrum (Fig. 4) characteristic of the class of $\beta$-II proteins [13] with a minimum ellipticity at about $200 \mathrm{~nm}$ and a slight positive shoulder at $225 \mathrm{~nm}$ [12]. In contrast to the CD spectrum of SKTI dissolved in buffer, the far-UV spectra (Fig. 4) and near-UV spectra (Fig. 5) from SKTI dissolved in either 19 or $190 \mathrm{mM} \mathrm{HCl}$ shows a markedly diminished ellipticity, presumably due to a loss of native conformation caused by electrostatic repulsion at low $\mathrm{pH}$. The spectra indicate a progressive loss in the extent of coil structure upon acidification as evidenced by the diminished ellipticity at 195 $\mathrm{nm}$. Smaller changes in ellipticity are seen at the region of $225 \mathrm{~nm}$. The loss of ellipticity was much less for SKTI dissolved in SGF without pepsin. Since SGF contains 80 $\mathrm{mM} \mathrm{HCl}$, we interpret this stabilization of structure as being due to the increased ionic strength because of the inclusion of $\mathrm{NaCl}$. Consistent with this interpretation was the observation that the mean residue ellipticity for SKTI dissolved in water was only approximately $-20,000$, relative to the value of approximately $-60,000$ when dissolved in $10 \mathrm{mM}$ sodium phosphate ( $\mathrm{pH}$ 7.2) buffer (data not shown). The ability of ionic strength to stabilize some of the SKTI native structure under acid conditions may account for the stability of SKTI to digestion by pepsin in SGF.

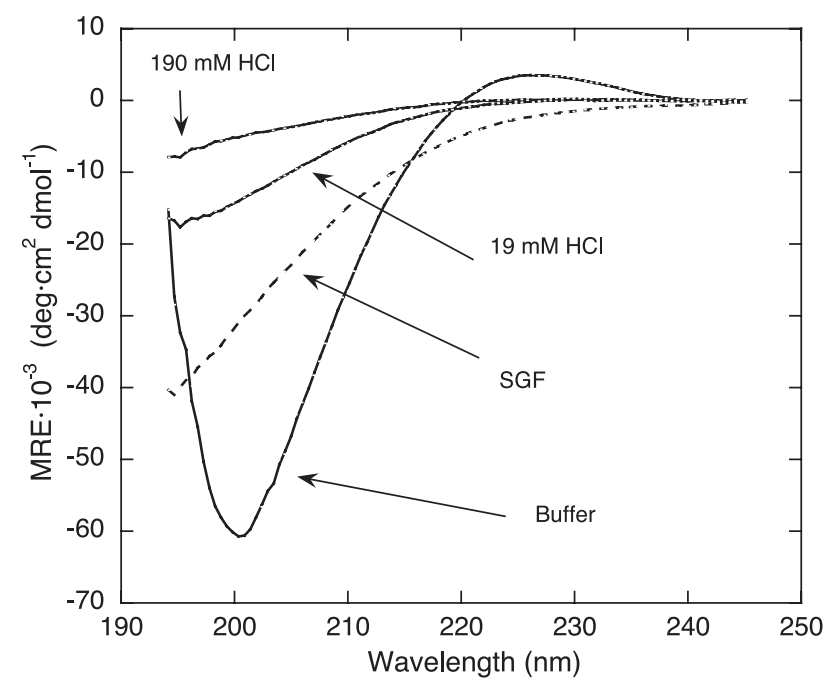

Fig. 4. Far-UV CD spectra of SKTI in $10 \mathrm{mM}$ sodium phosphate buffer, in $\mathrm{SGF}$, and in 19 or $190 \mathrm{mM} \mathrm{HCl}$ at $37{ }^{\circ} \mathrm{C}$.

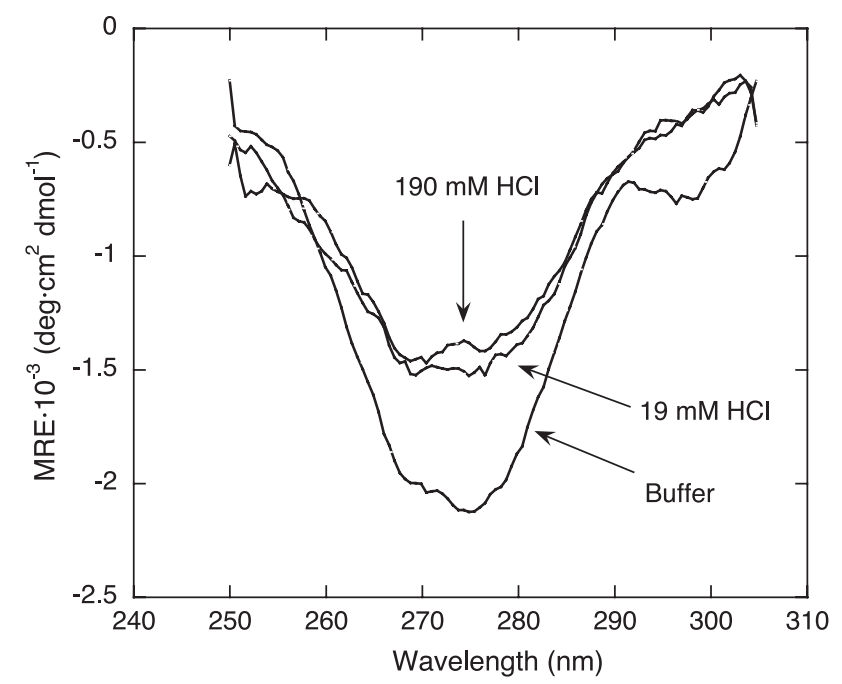

Fig. 5. Near-UV CD spectra of SKTI in $10 \mathrm{mM}$ sodium phosphate buffer, and in 19 or $190 \mathrm{mM} \mathrm{HCl}$ at $37{ }^{\circ} \mathrm{C}$.

\subsection{ANS fluorescence}

ANS fluorescence was measured at various concentrations of $\mathrm{HCl}$ to determine the extent of unfolding of the native structure of SKTI. The data in Fig. 6 show the fluorescence intensity of ANS at different $\mathrm{pH}$ values measured at $37{ }^{\circ} \mathrm{C}$. At lower concentrations of $\mathrm{HCl}$, there is negligible increase in fluorescence indicating minimal dye binding with the native protein. However, at 19,80 and 190 $\mathrm{mM} \mathrm{HCl}$ concentration, the fluorescence intensity is significantly increased, reflecting the ability of ANS to access the hydrophobic core of the molten state of SKTI. The $80 \mathrm{mM}$ $\mathrm{HCl}$ sample was SGF that also contained $34 \mathrm{mM} \mathrm{NaCl}$, which may account for the decrease in fluorescence inten-

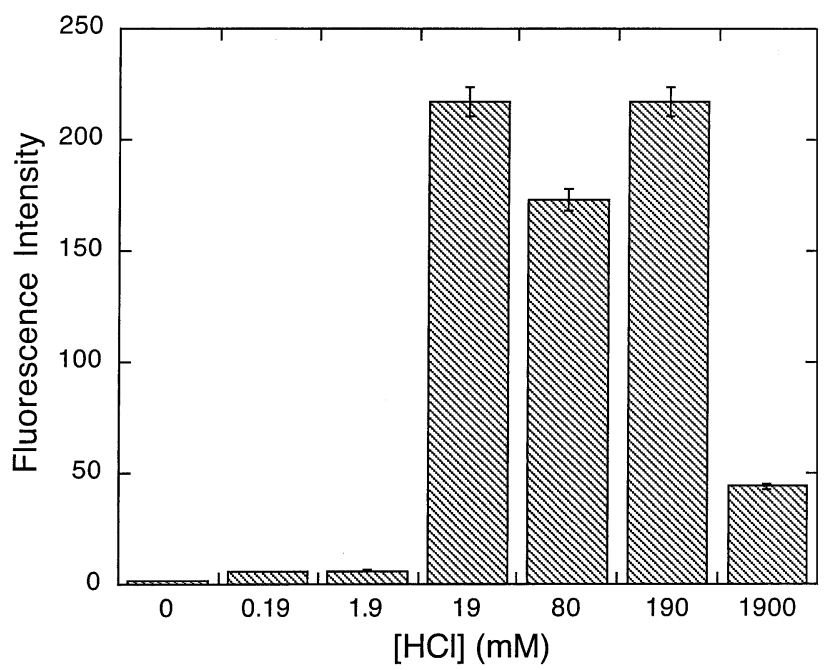

Fig. 6. ANS Fluorescence intensity with SKTI at different concentrations of $\mathrm{HCl}$. ANS fluorescence intensity of SKTI was measured at the indicated concentrations of $\mathrm{HCl}$ at $37{ }^{\circ} \mathrm{C}$. The $80 \mathrm{mM}$ treatment was SGF, also containing $\mathrm{NaCl}$. Excitation was at $390 \mathrm{~nm}$ and emission at $460 \mathrm{~nm}$. Each point is an average of three data points. 
sity. At $1900 \mathrm{mM} \mathrm{HCl}$, the fluorescence intensity sharply decreased, consistent with a loss of the secondary and tertiary structure upon total denaturation [23].

\section{Discussion}

Soy proteins have been estimated to be among the most common food allergens [24]. SKTI has been established as a minor component in the array of soy allergenic proteins based on IgE binding, skin prick tests and SGF proteolysis $[2,3]$. The beta-sheet structure of SKTI is shared with other allergens, consistent with its allergenic potential $[25,26]$. SKTI is a moderately abundant protein in soybean seeds. It is able to inhibit the enzyme trypsin and therefore may be involved in plant defense against herbivores [27]. In addition to presence in products prepared with soy proteins, it has been identified as one of four proteins generally present in soybean lecithin [4], a common emulsifier used in food production.

SKTI is highly resistant to denaturation and this has important consequences related to its role as an allergen. At the level of food processing, the resistance of SKTI to thermal denaturation and its renaturation after heating increases the likelihood that the allergenic epitopes may not be destroyed prior to consumption. After ingestion, failure to hydrolyze a protein such that it can be absorbed with a fully or partially intact conformation raises the possibility for presentation of stable epitopes to the immune system. Resistance to proteolysis in SGF has been used to commonly assess the allergenic potential of a protein [14] or to monitor the development of new potential allergens in transgenic crops.

We tested the resistance of SKTI to digestion in the pepsin-containing SGF system. SKTI was very resistant to proteolysis in SGF, with little protein loss during $60 \mathrm{~min}$ of incubation. Interestingly, reducing the disulfide bonds with DTT brings about rapid proteolysis in SGF indicating a marked change to a susceptible conformation, possibly equivalent to a hydrophobic collapse [7]. This reduction, however, may be dependent on the low standard redox potential of DTT $(-0.332 \mathrm{~V}$ at $\mathrm{pH} 7)$, since 2-mercaptoethanol at similar concentrations did not make the SKTI protein susceptible to pepsin hydrolysis. However, the differential reduction of internal disulfide bonds in allergens by DTT and thioredoxin has been well documented [28-30] and is not strictly dependent on the redox potential. This observation suggests that it may be possible to produce mutants in primary structure or to find homologues as natural sequence variants that are lacking one or more cysteine residues, thereby resulting in increased digestion and a reduced allergic potential.

In contrast to digestion in SGF, limited proteolysis with enzymes such as chymotrypsin is a technique of intermediate resolution that is commonly used to probe the conformational states of proteins during folding [31]. Native SKTI is resistant to proteolysis with either chymotrypsin at $\mathrm{pH} 8.7$ or pepsin in SGF, whereas heating SKTI to $90{ }^{\circ} \mathrm{C}$ results in a non-native conformation that is susceptible to proteolysis by both enzymes. The cooling of SKTI after heating to 90 ${ }^{\circ} \mathrm{C}$ leads to the reformation of a compact conformation as evidenced by its resistance to proteolysis. The rate of renaturation has some effect on the SKTI renatured structure as seen in the proteolysis with SGF. Gradual cooling leads to near complete recovery of a protease-resistant structure, but a sudden drop in temperature may trap a fraction of the inhibitor in misfolded conformations that undergo proteolysis with pepsin in SGF. Removal of SKTI during the gradual cooling process and treatment with chymotrypsin at $37{ }^{\circ} \mathrm{C}$ demonstrated a clear renaturation process with a midpoint centered at approximately $60{ }^{\circ} \mathrm{C}$. This is the same temperature that was previously observed to be the midpoint for changes in the UV absorption spectrum and ANS fluorescence intensity during sequential thermal denaturation and renaturation [12].

Based on its crystal structure and CD spectrum, SKTI has been classified with all antiparallel $\beta$-sheet proteins called the $\beta$-II or 'disordered' class of proteins. These proteins have CD spectra with minima at about $200 \mathrm{~nm}$ and a small positive shoulder at about $225 \mathrm{~nm}$. Acid denaturation studies have conventionally focused on regular $\alpha$-helical structures and much less is known about denaturation in this class of $\beta$-sheet structures. Thermal transition studies done with SKTI at neutral and alkaline $\mathrm{pH}$ are reversible [12,32]. CD spectra of SKTI during denaturation in the far-UV region show decreased ellipticity, indicating loss of secondary structure. These spectral changes are consistent with formation of a molten structure and substantiate increases observed in ANS fluorescence intensity [23].

Acid commonly induces a molten state in proteins [19]. Subjecting SKTI to increasing acidity by addition of $\mathrm{HCl}$ clearly resulted in a diminished ellipticity in the far-UV CD spectrum. We interpret our observations based on an increasingly positive protein charge as $\mathrm{pH}$ is lowered. The intramolecular electrostatic repulsion that results from the positive charges may cause some unfolding and a relatively extended conformation [17]. The progressive nature of this effect is seen by the additional loss of ellipticity at $190 \mathrm{mM}$ $\mathrm{HCl}$ relative to $19 \mathrm{mM}$. This acid-induced conformational change is clearly susceptible to the addition of cations as seen in the sample dissolved in SGF, containing $80 \mathrm{mM} \mathrm{HCl}$ and $34 \mathrm{mM} \mathrm{NaCl}$. The addition of the additional ionic strength is sufficient to cause significant screening of the electrostatic repulsion and result in an intermediate amount of ellipticity. We interpret the structures in $\mathrm{HCl}$ as the adoption of an open conformation that is still stabilized by the exposure of the hydrophobic interior residues to the aqueous environment. The presence of an open, somewhat molten structure is corroborated by the changes in ANS fluorescence intensity observed with increasing $\mathrm{HCl}$ concentrations. The lowest $\mathrm{HCl}$ concentrations caused little increase in ANS fluorescence, indicating any conformational change had not significantly exposed the hydrophobic interior. The ANS fluorescence intensity increases when 
incubated with SGF in 19 and $190 \mathrm{mM} \mathrm{HCl}$, but decreases when $\mathrm{HCl}$ concentration is increased to $1900 \mathrm{mM}$. This decrease is consistent with denaturation and exposure of the interior residues to the milieu.

The control of the acid-induced conformation exerted by $\mathrm{NaCl}$ is consistent with hydrophobic forces as the major driving forces in protein folding, while hydrogen bonding and electrostatic interactions guide the folding pathway [33]. The demonstration of an acid-induced molten state in SKTI assumes importance because this conformation is commonly involved in translocation of proteins across membrane barriers and even in membrane insertion [34]. The ability of a food protein to be an allergen may be related to its stability in the acid environment of the digestive system by assuming a more molten structure, which is also able to cross the gastrointestinal membrane barrier and thereby initiate the $\operatorname{IgE}$ response $[34,35]$.

In conclusion, our work in this report has demonstrated that thermal denaturation in SKTI is reversible, although somewhat dependent on the rate of renaturation. It has highlighted the importance of disulfide bonds in SKTI and suggested that these may be logical targets for the production of a hypoallergenic SKTI protein. It has also shown that SKTI is not fully denatured by the acidic conditions that commonly prevail in the gastric environment, explaining its ability to survive pepsin digestion in SGF. The notion that the more molten state that SKTI assumes in the stomach environment is related to its allergenicity due to increased membrane permeability may prove to be a useful hypothesis for further studies on the mechanism of food protein allergenicity.

\section{Acknowledgements}

Published as paper number 14342, Journal Series, Nebraska Agricultural Research Division. This work was supported by grant No. 03-00ER15099 from the U.S. Department of Energy (J.M.) and in part by NIH Grant Number 1 P20 RR16469 from the BRIN Program of the National Center for Research Resources (G.S.).

\section{References}

[1] M. Kunitz, Science 101 (1945) 668-669.

[2] S. Quirce, F.M. Nieto, F. Polo, J. Sastre, J. Allergy Clin. Immunol. 109 (2002) 178.
[3] A.W. Burks, G. Cockrell, C. Connaughton, J. Guin, W. Allen, R.M. Helm, Int. Arch. Allergy Immunol. 105 (1994) 143-149.

[4] X. Gu, T. Beardslee, M. Zeece, G. Sarath, J. Markwell, Int. Arch. Allergy Immunol. 126 (2001) 218-225.

[5] R.M. Sweet, H.T. Wright, J. Janin, C.H. Chothia, D.M. Blow, Biochemistry 13 (1974) 4212-4228.

[6] H.K. Song, S.W. Suh, J. Mol. Biol. 275 (1998) 347-363.

[7] J. Tetenbaum, L.M. Miller, Biochemistry 40 (2001) 12215-12219.

[8] R.F. Steiner, Biochim. Biophys. Acta 100 (1965) 111-121.

[9] K. Lehle, A. Wrba, R. Jaenicke, J. Mol. Biol. 239 (1994) 276-284.

[10] S.E. James, R.C. Freed, D.S. Ryan, Biochim. Biophys. Acta 701 (1982) 237-241

[11] B.S. Leach, W.W. Fish, J. Biol. Chem. 252 (1977) 5239-5243.

[12] R. Roychaudhuri, G. Sarath, M. Zeece, J. Markwell, Arch. Biochem. Biophys. 412 (2003) 20-26.

[13] G.D. Fasman, Circular Dichroism and the Conformational Analysis of Biomolecules, Plenum, New York, 1996.

[14] J.D. Astwood, J.N. Leach, R.L. Fuchs, Nat. Biotechnol. 14 (1996) $1269-1273$.

[15] T. Yagami, Y. Haishima, A. Nakamura, H. Osuna, Z. Ikezawa, J. Allergy Clin. Immunol. 106 (2000) 752-762.

[16] R.D. Huby, R.J. Dearman, I. Kimber, Toxicol. Sci. 55 (2000) $235-246$.

[17] Y. Goto, L.J. Calciano, A.L. Fink, Proc. Natl. Acad. Sci. U. S. A. 87 (1990) $573-577$

[18] A.L. Fink, L.J. Calciano, Y. Goto, T. Kurotsu, D.R. Palleros, Biochemistry 33 (1994) 12504-12511.

[19] L.O. Narhi, J.S. Philo, T. Li, M. Zhang, B. Samal, T. Arakawa, Biochemistry 35 (1996) $11454-11460$.

[20] M. Bradford, Anal. Biochem. 72 (1976) 248-254.

[21] D.M. Bollag, S.J. Edelstein, Wiley-Liss, New York, 1991, pp. 50-51.

[22] U.K. Laemmli, Nature 227 (1970) 680-685.

[23] G.V. Semisotnov, N.A. Rodionova, O.I. Razgulayev, V.N. Uversky, A.F. Gripas, R.I. Gilmanshin, Biopolymers 31 (1991) 119-128.

[24] H.A. Sampson, C.C. McCaskill, J. Pediatr. 107 (1985) 669-675.

[25] R.C. Aalberse, J. Allergy Clin. Immunol. 106 (2000) 228-238.

[26] P.R. Shewry, F. Beaudoin, J. Jenkins, S. Griffiths-Jones, E.N.C. Mills, Biochem. Soc. Trans. 30 (2002) 906-910.

[27] D.S. Park, M.Y. Graham, T.L. Graham, Physiol. Mol. Plant Pathol. 59 (2001) $265-273$

[28] J.H. Wong, K. Kobrehel, B.B. Buchanan, Methods Enzymol. 252 (1995) 228-240.

[29] K. Kobrehel, B.C. Yee, B.B. Buchanan, J. Biol. Chem. 266 (1991) $16135-16140$

[30] K. Kobrehel, J.H. Wong, A. Balogh, F. Kiss, B.C. Yee, B.B. Buchanan, Plant Physiol. 99 (1992) 919-924.

[31] I. Kheterpal, A. Williams, C. Murphy, B. Bledsoe, R. Wetzel, Biochemistry 40 (2001) $11757-11767$.

[32] Y.V. Wu, H. Scheraga, Biochemistry 1 (1962) 905-911.

[33] Y. Goto, A.L. Fink, Biochemistry 28 (1989) 945-952.

[34] V.E. Bychkova, O.B. Ptitsyn, Chemtracts, Biochem. Mol. Biol., (1993) 133-163.

[35] G.R. Burnett, M. Wichham, A. Fillery-Travis, J.A. Robertson, P.S. Belton, S.M. Gilbert, A.S. Tathm, P.R. Shewry, E.N.C. Mills, Biochem. Soc. Trans. 30 (2002) 916-918. 